\title{
INTRODUCTION OF LEAN MANUFACTURING PHILOSOPHY BY KAIZEN EVENT: CASE STUDY ON A METALMECHANICAL INDUSTRY
}

\author{
Vinicius Mitsuo Kojima Campos \\ State University of Maringá - UEM, Departament of Production \\ Engineering, Brazil \\ E-mail: kojima@gmail.com \\ Syntia Lemos Cotrim \\ State University of Maringá - UEM, Departament of Production \\ Engineering, Brazil \\ E-mail: syntialceng@gmail.com \\ Edwin Vladmir Cardoza Galdamez \\ State University of Maringá - UEM, Departament of Production \\ Engineering, Brazil \\ E-mail: evcgaldamez@uem.br \\ Gislaine Camila Lapasini Leal \\ State University of Maringá - UEM, Departament of Production \\ Engineering, Brazil \\ E-mail:gclleal@uem.br
}

Submission: 14/10/2015 Accept: 30/10/2015

\section{ABSTRACT}

The competitive scenario requires organizational strategies increasingly elaborated, creating the need of companies to structure their management models in order to absorb these conflicts generated by competition. The manufacturing area is financially affecting deeply the company's results, thus process improvement comes as the organization's survival guideline, and the rationalization of waste without the need for high investments, shown a great competitive alternative. The application of Kaizen event seeks to measure the benefits generated by the implementation of the philosophy of lean manufacturing, working setup aspects of machinery, the manufacturing process flow, reduced delivery lead-time and inventory process. The Kaizen Blitz was applied in a production cell of stamping and spirt processes. 
The obtained major improvements have been the reduction of machine setup time, reducing lead-time of item processing, the material flow within the production cell, and creating conditions for a more flexible management of the production schedule.

Keywords: Lean Manufacturing; Kaizen; Continuous Improvement; Waste Reduction.

\section{INTRODUCTION}

With ongoing globalization process, consumer markets end up creating high levels of criticality, challenging the survival of organizations demanding better levels of productivity and quality, putting in proof their management methods.

In manufacturing, the pursuit of excellence provides management with the target pointed to waste of the production chain, defined as an activity that absorbs resources and creates no value (WOMACK, 1998). After World War II the need for a competitive industry inspired the Japanese to develop a set of new practices that would leverage its competitiveness.

These practices were called up as lean manufacturing techniques, where processes leading to overproduction, waiting times (people and equipment); errors that require correction, unnecessary inventories, excessive transport of materials and movement of people are uniformed to continuous improvement actions (WOMACK, 1992).

High levels of quality, productivity and competitiveness stimulated actions seeking continuous streams, machinery and manpower in the best sequence of activities, aimed at reducing waste in order to add value without interruption by setting guidelines called Lean Thinking, created by Taiichi Ohno (PASCAL, 2008).

According to Correa and Vieira (2008), the representativeness of the results that the Lean Manufacturing methodology or lean production, which had as precursors Eiji Toyota and Taihichi Ohno of Toyota Motor Company has been a recognition of movement in the Western world. The Lean Manufacturing methodology became part of the organizations competitive strategy, providing productivity improvements whose interest is to reduce costs, increase the availability of resources, increase efficiency and reduce waste. 
DOI: 10.14807/ijmp.v7i1.388

The work developed by Peinado and Graeml (2014) concluded that in practice of Operations Management by the corporations analyzed; among the most referenced topics in the contents of main documents that direct to the production systems two of them stand out: quality management $(20.3 \%)$ and lean production system (with 15.8\%) demonstrating the relevance of lean production in production systems.

According to Imai (1996), the spread of Lean Thinking can be stimulated through Kaizen events, setting up projects aimed at optimizing existing resources, speed in the implementation of changes, active employee participation, small steps and continuous approach of the established goal. These short-term results end up promoting the alignment of corporate guidelines with his cast through compromise. Karlsson and Ahlström (1996) state that the Lean objectives address the reduction of waste, improved quality, increased productivity, reduced setup times and reducing costs.

In the process of continuous improvement, what actually have significance is to choose the moment of improvement even if it is the minimum possible, not how much should be improved. Any process can be analyzed in a different light undergoing positive changes every hour, day, week or month, and the important thing is that some improvement has taken place, further improving the processes and influencing the organization's maturity level.

However, the ability of continuously improve does not occur naturally, and requires involvement from top management to operators, where the break paradigms include the absorption of new values, specific skills, behaviors and actions aimed at continuous improvement, supported by a philosophy dedicated to results (HARRINGTON, 1997). Gonzalez and Martins (2011) confirm that the simple implementation of programs and tools for troubleshooting is not enough, it is necessary that organizations encourage learning and cooperation among its employees through the development of human resources for such improvement initiatives are in fact continuous.

In most manufacturing companies, the highest concentration of their capital is invested and focused on the production sector, where productive resources (labor, machinery and raw materials) require an increasingly mature management. The 
DOI: 10.14807/ijmp.v7i1.388

company granting the study created a need for changing their behavior so some strategic objectives can be met, such as increase of productivity, attracting new consumer markets, increase of customer satisfaction and pursuit of industry leadership. The choice of a lean production as a competitive strategy was given by the example of the method efficiency applied to various sectors of manufacturing.

In this context, this paper aims to operationalize the concepts of lean manufacturing through the development of Kaizen Blitz, i.e., small projects that optimize existing resources in the short term, with low investment, active participation of employees and the approach of previously defined goals.

This text is structured into four sections besides this introduction. The second section presents the theoretical framework of Kaizen philosophy. The third section describes the research method adopted. The fourth section describes the fieldwork. Finally, the fifth section presents the contributions and limitations of this work.

\section{KAIZEN PHILOSOPHY}

To Chen et al., (2000) Kaizen is a Japanese word that has become common in many Western companies. According to Ashmore (2001) Kaizen originated in Japan in 1950 when the management of industries and government recognized that there was a problem in the current system of management creating a labor shortage. Kaizen is a kind of thinking and management, i.e., a philosophy to be used not only in management but also in everyday life. This means a gradual and continuous progress, intensification and improvement (ASADA et al., 2000).

The process of continuous improvement is the expression that comes closest to the translation of the meaning of Japanese culture Kaizen, though not solely to process improvement, such as the manufacture of products, services, customer service, relationships with suppliers and unions (KOSANDAL; FARRIS, 2004).

There are two levels of Kaizen: Kaizen of Flow: or of system, that focuses on the value stream, addressed to the management; Kaizen of Process: focuses on individual processes, directed work teams and team leaders (ROTHER; SHOOK 2003); (MALIK; YEZHUANG, 2006).

The basis of Kaizen consists of simple concepts but no less important as $5 \mathrm{~S}$, set by Japanese experts as a set of morals and manners, resulting from the 
DOI: 10.14807/ijmp.v7i1.388

traditional form of behavior at home and at school (MICHALSKA; SZEWIECZEK, 2007). The generality and simplicity of Kaizen ranges from activities that focus on the development of solutions in the Gemba (factory floor), the implementation of a predetermined plan changes, the fluidity of course paperwork, assuming various levels of involvement and magnitude of projects.

Kaizen event is characterized as a technique that realizes improvements in both deployment both in a production process and in administrative process. It is a technique for the rapid implementation of improvements, with the effective participation of the operational level. This type of event is in a short-term intensive effort to improve dramatically the performance of a limited scope process (LIMA, 2010). The events aim to maximize productivity without generating an increase in cost, and may take different levels of coverage, emphasizing teamwork because each Kaizen Event is formed a cross-functional team of operators, engineers, people of the administrative sector, suppliers and sometimes outsiders.

With work focused, the team identifies the problem and the attacks from several angles, encouraging creative solutions, therefore, since the team approved the idea, improve is deployed immediately with the full support of the organization (CHAVES, 2010).

Depending on the lean tool that needs to be deployed, the event's scope defines the extent of the schedule, with their respective schedule, number of participants and technical requirement level, taking into account some key features (CHAVES, 2010):

a) Forming a team of up to 12 people.

b) To fulfill the mission in five days.

c) Staff should be entirely focused on the mission to be fulfilled.

d) The dedication must be unique and not having anything else to do next week.

e) It has priority in the use of manufacturing resources and obtaining information.

The Kaizen differs from traditional processes of continuous improvement because it is almost entirely based on action, where teams are responsible for the 
DOI: 10.14807/ijmp.v7i1.388

development and implementation of its solutions by employing another level of efficiency and speed, creating or changing processes and letting a new in place (LIMA, 2010).

Singh and Singh (2009) state that the Kaizen philosophy sparked considerable interest among researchers because it increases the company's productivity and helps produce high quality products with minimal effort.

\section{RESEARCH METHOD}

The nature is an applied research, wherein the approach is quantitative, where a performance analysis of the proposed solutions has been performed. Moreover, objectives' perspective, the research is exploratory (GIL, 2010).

The steps involved in the research were:

- To characterize the company and the process to be analyzed;

- Perform Kaizen Event in the cell of manufacture of the component observed;

- Quantitatively evaluate the results employed by Kaizen event by analyzing the output from the cell, the process flexibility and the work piece processing time;

- Qualitatively assess the improvements proposed by Kaizen Event, analyzing the physical organization of the cell, ease of running the operating procedure and the motivation of the operator.

The start of the project was given according to a tactical direction where an analysis of results of the production cell in question cast doubt on the efficiency, evaluating critically deliveries of the cell at a given time. It is important to highlight that in a previously moment it had already been performed a valuable analysis on the entire production process of the company, which turned out to outline the priorities of events, listing in order to sort the projects according to their impact on the outcome of production.

First, a leader chose a team of multifunctional employees who focused on information and directed the development of the project. Later, after team recruitment, all the information inherent to the cell manufacturing process were mapped, highlighting important factors in the outcome of cell, such as: capacity, delivery lead time, delivery volume, overall efficiency, production flow and setup time. 
DOI: 10.14807/ijmp.v7i1.388

On further analysis of the collected data, general and secondary objectives of the project were defined, and considering that the kaizen event aims to eliminate waste from the process, the main problems that limit the results of the manufacturing cell were stated. After a critical analysis of these problems, it was outlined an action plan for the permanent elimination of the causes that determined a significant impact level for the process.

In the stage of action plan implementation, it were delegated the deliveries of each team member according to their specific expertise, in which they became responsible for "pulling" the actions within an agreed schedule among all. A quantitative analysis was performed at the end of a period of adjustment, where the same indicators that have been raised at the beginning of the project are reevaluated, generating a feedback of improvements implemented. For a qualitative perception of improvement of the subjective criteria such as, organization of physical means of production cell, satisfaction and commitment of the operator and ergonomics from operating activities were evaluated.

\section{FIELD RESEARCH}

This section presents the characteristics of the process, efficiency analysis and the conducted Kaizen blitz.

\subsection{Process Characterization}

The object of this research study is a company located in the Northern of Parana state, active in the metal mechanical sector. With a staff ranging between 160 and 170 employees, sells its products throughout MERCOSUR territory. Its manufacturing sector is subdivided into three areas, two of which are responsible for manufacturing components that feed an assembly line where the finished products are designed.

The observation of the study and all its systematic was directed to one of the cells that manufacture part component of the final product, adding seven models similar in their geometrical characteristics, however, different with respect to their dimensions. As an example, it was called "component", the processed object on the premises of the cell and increasingly compared to their size, gain an alphabetical reference to differentiate themselves from others (Component $A, B, C, D, E, F, G$ ) . 
DOI: 10.14807/ijmp.v7i1.388

The component manufacturing process is identical for all models, and the beginning of the transformation is given by cutting the flat steel plate, which is received from the supplier in accordance with a specification of measurements (thickness, width and length), ensuring cutting process efficiency.

This raw sheet is processed in a cutter which supplies not only the cell component, but also a second cell fabrication, which for its part subsequent process, another cut, and giving rise to its final geometry. With the aid of a matrix, the hydraulic press (hydraulic press 1) making the second cut in the steel sheet, which undergoes a drawing process in its third manufacturing step, also by dies, but in a second hydraulic press (hydraulic press 2 ). And as a final step of adding value have the fourth component of the processing step, characterized by making an edge component at the bottom.

As processes still belonging to the manufacturing process under study, being cited as a last process that occurs during the component processing, washing, that does not add value to the product, but is essential for the subsequent operation, welding. Besides washing process, it can be mentioned handling and waiting processes between guillotine cutting and cutting processes by the hydraulic press 1 , and between the crimping process and component washing.

Two operators are required to operate the guillotine, and a third operator is responsible for manufacturing the component that passes through the presses and curler, and a fourth operator is prompted when the washing of the caps is required to be used in the welding process.

The materials handling processes are the industry leader's responsibility using the forklift to move the lots that are processed in the guillotine and going from guillotine to the hydraulic press 1 . The machine operator himself, who also carried the loading and unloading machines, moves the component one by one into the manufacturing cell.

A materials mover is responsible for moving the ready dirty components, stored in metal boxes, for an intermediate warehouse. The storage and handling of the batch back to the cell, which is required when the washing of the components for its use is needed in the welding process; it is also within the competence of materials mover. 
DOI: 10.14807/ijmp.v7i1.388

It is important to point out that the two hydraulic presses and curler make use of tools dedicated to the manufacture of component models and every time is required to manufacture a particular model, conducting a setup (machine preparation) is required, which is held by the industry leader and also the operator of the presses and curler. Figure 1 shows the layout of machines and the path followed by the piece within the cell.

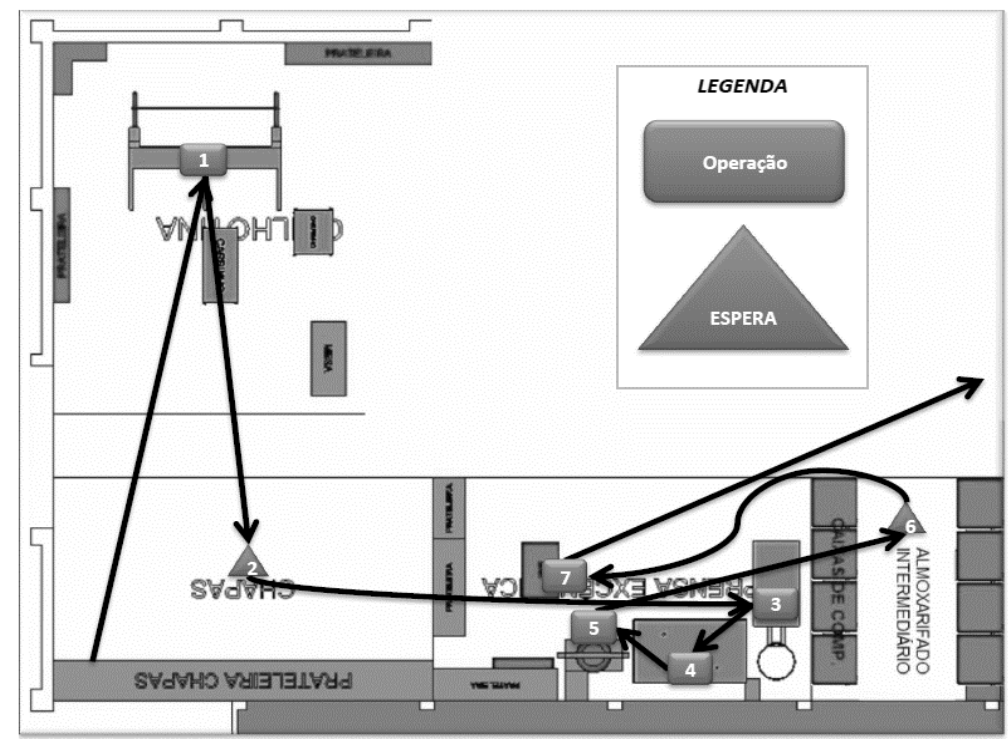

Figure 1: Process Flowchart map

\section{a) Efficiency Analysis}

Quantitatively showing the line efficiency, first it was checked the monthly productivity of the manufacturing cell, considering a one year period. In order to get a sense of how efficient the cell was being information of the volumes produced in the period according to their models were gathered up, and to analyze the efficiency, the actual production information to conflicted with a planned production generating an indicator of cell efficiency, which indicated $75 \%$.

Mapping the process and sizing the capacity of each workstation, observe the possible bottlenecks and also the activities that do not add value to the process of transformation. It is important to conflict the process capability data and manufacturing Lead Time, thereby obtaining an idea of how much waste the process is suffering.

Table 1 illustrates the operational sequence for the manufacture of components and also the analysis data for the capacity parameters and process processing time. 
INDEPENDENT JOURNAL OF MANAGEMENT \& PRODUCTION (IJM\&P)

http://www.ijmp.jor.br

v. 7, n. 1, January - March 2016

ISSN: 2236-269X

DOI: 10.14807/ijmp.v7i1.388

Table 1: Manufacturing Process Capability

\begin{tabular}{|c|c|c|c|c|c|c|c|c|c|}
\hline \multicolumn{10}{|c|}{ Capabilitv analisvs of the manufacturing process } \\
\hline 岁 & \multicolumn{2}{|l|}{ Process Description } & & $\begin{array}{l}\frac{\pi}{5} \\
\text { है } \\
\frac{1}{5} \\
\text { है } \\
\end{array}$ & 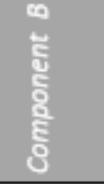 & 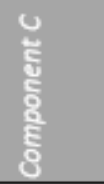 & 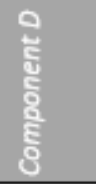 & 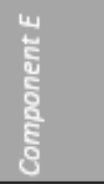 & 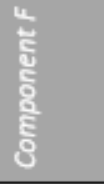 \\
\hline 1 & \multicolumn{2}{|l|}{ Cutting 1 of the steel plate } & 0,60 & 0,60 & 0,60 & 0,67 & 0,67 & 0,70 & 0,70 \\
\hline 2 & \multicolumn{2}{|l|}{ Waiting (Cutting Plate) } & 240,00 & 240,00 & 240,00 & 240,00 & 240,00 & 240,00 & 240,00 \\
\hline \multirow{2}{*}{3} & \multirow{2}{*}{ Cutting 2 of the steel plate } & TM & 0,20 & 0,29 & 0,18 & 0,22 & 0,22 & 0,20 & 0,38 \\
\hline & & TA & 0,20 & 0,22 & 0,20 & 0,18 & 0,18 & 0,70 & 0,27 \\
\hline \multirow{2}{*}{4} & \multirow{2}{*}{ Spirt } & TM & 0.29 & 0,30 & 0.17 & 0,08 & 0,08 & 0,30 & 0,33 \\
\hline & & TA & 0,52 & 0,38 & 0,50 & 0,40 & 0,40 & 0,50 & 0,62 \\
\hline 5 & \multirow{2}{*}{ Curling } & TM & 0,08 & 0,12 & 0,08 & 0,10 & 0,10 & 0,10 & 0,18 \\
\hline ? & & TA & 0,32 & 0,35 & 0,37 & 0,30 & 0,30 & 0,38 & 0,38 \\
\hline 6 & \multicolumn{2}{|c|}{ Waiting (Readv dirtv component) } & 960,00 & 960,00 & 960,00 & 960,00 & 960,00 & 960,00 & 960,00 \\
\hline 7 & \multirow{2}{*}{\multicolumn{2}{|c|}{$\begin{array}{c}\text { Washing } \\
\text { Component eadtime }\end{array}$}} & 0,22 & 0.22 & 0,27 & 0,35 & 0,35 & 0,43 & 0,53 \\
\hline & & & 1202,43 & 1202,48 & 1202,37 & 1202,30 & 1202,2 & 1203,31 & 1203,39 \\
\hline & \multirow{2}{*}{\multicolumn{2}{|c|}{$\begin{array}{c}\text { Process Capacity } \\
\text { Takt time }\end{array}$}} & 1,39 & 1,53 & 1,30 & 1,42 & 1,46 & 1,73 & 2,12 \\
\hline & Takt time & & 1,83 & 1.83 & 1,83 & 1.83 & 1,83 & 1.83 & 1,83 \\
\hline
\end{tabular}

Other process parameters were also evaluated, for example, economic batch size which determines the quantity to be processed and subsequently stored volume. This inflexibility adds number characteristic to the process by limiting the variability models that can be processed in a same time interval.

The setup time also has significant influences to the process, determining the machine stop time needed for the preparation inherent in the production of a different model from the foregoing that had been processed, limiting the time available for production.

\section{b) Kaizen Blitz}

The realization of the Kaizen Blitz followed a phased order constituting the project in six steps, arranged in: 1) Training of staff; 2) Critical Analysis of the Process; 3) Opportunities for Improvement; 4) Action Plan; 5) Presentation of Results; and, 6) Checklist.

First it was recruited a team of 12 people from different sectors, each of which would have a different assignment in the project. Through integration, a group dynamic was held, where the main goal was to show the team problem-solving capacity and start the group socialization.

Later, it was performed an analysis of the current situation of the process, which were highlighted aspects of unproductive and waste, such as: Deficit of the produced volume, process inventories, machine time stopped and physical effort of 
INDEPENDENT JOURNAL OF MANAGEMENT \& PRODUCTION (IJM\&P)

http://www.ijmp.jor.br

v. 7, n. 1, January - March 2016

ISSN: 2236-269X

DOI: 10.14807/ijmp.v7i1.388

the operator. From this analysis, the project objectives were established, which were summarized in five key goals:

- Ensure the production of 5040 components / month

- Reduce setup time of hydraulic presses by at least $50 \%$

- Increase the productivity of the cell by $15 \%$

- Implement $1^{\text {st }}$ and $2^{\text {nd }}$ "S" of the $5 S$ program

- Implement at least five actions safety / ergonomics

Defining the main action plan guidelines, there was a brainstorming where the main aspects of the process to be improved were found. Table 2 shows the improvement opportunities that guided the drafting of the action plan.

Table 2: Opportunities for Improvement

\begin{tabular}{|c|l|l|}
\hline Item & Improvement opportunity & Attribute \\
\hline 1 & Very high Setup total time & Setup \\
\hline 2 & Lack of process flexibility before the variation of designs & Productivity / Setup \\
\hline 3 & Restriction of the use of forklift for moving the matrix & Setup \\
\hline 4 & Difficulty in the movement of materials within the cell & Ergonomics \\
\hline 5 & Difficulty in positioning the matrix during Setup & Setup / Ergonomics \\
\hline 6 & Excessive movement of the operator to pick up tools & Setup \\
\hline 7 & Difficulty of fixing the matrix during Setup & Setup / Ergonomics \\
\hline 8 & The need for another operator to washing of the components & Productivity \\
\hline 9 & Excess moving of materials & Productivity \\
\hline 10 & High volume of work in process & Productivity \\
\hline 11 & Lack for standard to operations flow in the cell & Operating standard \\
\hline 12 & Process of components washing manual & Productivity \\
\hline & & \\
\hline
\end{tabular}

These aspects were highlighted as crucial to meet the objectives of the project, they are circumstances that directly impact the results of the cell, limiting their efficiency in order to generate various waste for the manufacturing process.

In order to add value to the component manufacturing process, it was made an action plan that had as main objective to assign to the process, the characteristics required to fulfill their initial goals of the Blitz. Table 3 highlights the actions that have been implemented and that relates each improvement. 
DOI: 10.14807/ijmp.v7i1.388

With the creation of new production flow, the stage of products waiting to be washed could be eliminated, creating the product condition out of the manufacturing process finished, reducing considerably the process components, the manufacturing lead time (reduction 99\%), besides eliminating the need for an operator for the activity of components washing.

Table 3: Kaizen Components Action Plan

\begin{tabular}{|c|c|c|}
\hline Item & Action & Improvement / Investment \\
\hline 1 & $\begin{array}{l}\text { Implement pneumatic fasteners to fix the } \\
\text { matrices in the setup process }\end{array}$ & Hydraulic fixer \\
\hline \multirow{3}{*}{2} & \multirow{3}{*}{$\begin{array}{l}\text { Create conditions for easy positioning and } \\
\text { adjustment of the matrices in the setup process }\end{array}$} & Hydraulic ruler with transfer spheres \\
\hline & & Table base "T" \\
\hline & & Mobile positioning Door-post \\
\hline \multirow{3}{*}{3} & \multirow{3}{*}{ Eliminate the use of forklift in the setup process } & Removable arm with transfer spheres \\
\hline & & Cart to setup with transfer spheres \\
\hline & & Rack with rollers \\
\hline 4 & $\begin{array}{l}\text { Create continuous flow of operations and } \\
\text { eliminate waiting products for washing }\end{array}$ & Operating Procedure \\
\hline \multirow{3}{*}{5} & \multirow{3}{*}{$\begin{array}{l}\text { Create physical conditions for the crimping of } \\
\text { the components followed by washing caps }\end{array}$} & Packing to product available for welding \\
\hline & & Windy manual to drive components \\
\hline & & Trough to waiting process components \\
\hline \multirow{3}{*}{6} & \multirow{3}{*}{$\begin{array}{l}\text { Create new layout incorporating the flow of } \\
\text { activities and the setup process without the use } \\
\text { of forklift }\end{array}$} & New Layout project \\
\hline & & Crane Service for moving machines \\
\hline & & Electric and pneumatic installations \\
\hline \multirow{3}{*}{7} & \multirow{3}{*}{$\begin{array}{l}\text { Arrange the environment so that every physical } \\
\text { element of the cell has local and proper } \\
\text { identification }\end{array}$} & Tools Panel \\
\hline & & $\begin{array}{l}\text { Panel to project consultations and production } \\
\text { orders }\end{array}$ \\
\hline & & Identification of the tools, dies and components \\
\hline
\end{tabular}

The creation of the new layout has absorbed the necessary conditions for the creation of continuous flow of productive operations of the cell, it also provided the possibility of the setup process be performed behind the hydraulic presses, creating conditions for fixing and positioning activities to be carried out parallel to exchange of matrices.

With the installation of hydraulic fasteners to the process of establishment of matrices, the time of activity loosen and tighten the fasteners was reduced considerably, generating approximately 20 minutes time savings in the setup process. These fasteners aims the same function as screws, nuts and washers, however the hydraulic clamp supported at two points between extremity of the matrix and the base of the hydraulic press, hydraulic oil is triggered by generating a compressive force in the fixed parts. 
DOI: 10.14807/ijmp.v7i1.388

There was a precarious organization condition of tools and resources available and used in the manufacture of cell, moreover, there was no markings on the floor of the safe areas of the cell, or entry and exit of materials, ended up causing a chaos of components within the cell.

Thus a job that will provide any employee to find quickly and easily all the features of the cell was achieved, beyond the easy reference of information required for manufacturing (technical specifications of projects and production orders). The physical boundaries of the cell have also been standardized, useful area of the cell, input area and output materials and scrap disposal area.

For process control, some indicators that would guide the decision making of managers in the area have been standardized, as the continuous improvement process do not finish when the implementation of the actions is carried out, there is a need to check the results through analysis criticism that guide decision-making. Table 4 presents the indicators proposed for monitoring cell. For each indicator is described its purpose, timing, expression and goal.

Table 4: Production Indicators, Process and Quality

\begin{tabular}{|c|c|c|c|c|}
\hline Index & Objective & Periodicity & Formula & Goal \\
\hline $\begin{array}{l}\text { Production } \\
\text { volume }\end{array}$ & $\begin{array}{l}\text { Generate } \\
\text { feedback on the } \\
\text { achievement of } \\
\text { goals for the } \\
\text { planned } \\
\text { production } \\
\text { volume of each } \\
\text { component }\end{array}$ & Weekly & $\frac{\text { Produced Volume of the } x \text { component }}{\text { Planned Volume of the } x \text { component }}$ & $100 \%$ \\
\hline Efficiency & $\begin{array}{l}\text { Generate } \\
\text { feedback for } \\
\text { short-term } \\
\text { decisions by daily } \\
\text { cell efficiency }\end{array}$ & Daily & $\frac{\text { Total produced Volume }}{\text { Total Planned Volume }}$ & $100 \%$ \\
\hline $\begin{array}{l}\text { Schedule } \\
\text { appointmen } \\
t\end{array}$ & $\begin{array}{l}\text { To evaluate the } \\
\text { efficiency of } \\
\text { production by } \\
\text { component model }\end{array}$ & Schedule & Production volume of the component $x>$ Processing capacity & $85 \%$ \\
\hline Setup time & $\begin{array}{l}\text { To evaluate the } \\
\text { efficiency of the } \\
\text { machines } \\
\text { preparation } \\
\text { process }\end{array}$ & Unit & Total setup time & $\begin{array}{l}<30 \\
\text { min. }\end{array}$ \\
\hline Cull & $\begin{array}{l}\text { Evaluate the } \\
\text { quality of service } \\
\text { and processing } \\
\text { provided by the } \\
\text { production cell }\end{array}$ & Monthly & $\frac{\text { Culled components }}{\text { Produced Componsnts }}$ & $<5 \%$ \\
\hline
\end{tabular}


DOI: 10.14807/ijmp.v7i1.388

\section{FINAL CONSIDERATIONS}

The adherence to lean manufacturing and organizational strategy provides a big difference to the sustainability of organizations. Create conditions to do more with less is the great challenge for companies competing in the market, and the concept of waste disposal processes, enable a product with higher added value at a very competitive cost.

The study was intended to demonstrate the gains that the implementation of process improvement methodology, guarantee significant results only companies with a better structured combination of existing resources. However the greatness that these improvements are implemented, derived from the process maturity level, and in sometimes still needed some investments.

Starting from a condition where the process taken as an object of analysis could not achieve planned results, it sought to create conceptual alternatives for the resolution of problems through lean manufacturing. Thus, as a result of the literature review the practical part of the research was structured demonstrating the routines of kaizen event, and their respective deliveries, becoming more "tangible" the presentation of project execution.

The method of process improvement through Kaizen events provides a position to act on various critical processes of the value chain in a short period of time, and consume little runtime and have a low budget implementation, enable the consolidation of improvement continuous processes, by creating an organizational culture that prey by optimizing and facilitating the work.

It is true that the change bothers to break paradigms that are created after a certain accommodation of one's work routine, but it is clear that the incorporation of this philosophy becomes clearer when one suffering influence of certain events, notice the ease in their day by day.

The way it should be conditioning the method depends on several organizational factors, such as organizational culture, organizational structure, process maturity, availability of resources and so on, but it is important that every business understands the peculiarities and understand the proposal philosophy. 
DOI: 10.14807/ijmp.v7i1.388

For the process, one can highlight various aspects that have been improved, for example, lead product delivery team, decrease in set time, gains in productivity, processing pattern, decreased physical effort of the operator and greater operator involvement with the company's results. This is the main goal of philosophy Lean Manufacturing, reduce waste of value adding processes, generating most significant findings with the efficiency of processes.

Making operators believe the changes that were proposed was somehow a limitation of the project, since its criticality before the proposed projects was limited, since it was the first contact with the concept. Many lack of understanding of the proposals caused a rejection of the changes, and the operator had just insisting on older operating addictions, ending often angry with the new routine.

This factor required certain skills of project managers and area to spread the proposal of cultural change, creating conditions for the operator realized that what was being proposed was for their own job satisfaction, creating conditions so that their work could be run more easily and efficiently, and contribute to the company's costs.

The available time for training was also a critical factor of the project. Just training was given in order to familiarize the people involved in the project that had never had contact with the subject. This circumstance turned out to aggravate both the issue of operator resistance, as well as the sense of urgency in implementing the activities. The full availability of some project members reduced the dedicated time for carrying out the planned actions, causing the delay of some deliveries, delaying the implementation and realization of the plan. In addition, the precarious nature of some features, there was need for some investments that increased the project budget, and the deadlines for implementing those actions had to be extended due to lack of availability of resources for the financing of acquisitions.

\section{REFERENCES}

ASADA, T.; BAILES, J.C.; SUZUKI, K. (2000). Implementing ABM with Hoshin Management. Institute of Management Accountants Publ., New Jersey.

ASHMORE, C. (2001). Kaizen and the Art of Motorcycle Manufacture.

Manufacturing Engineer, v. 80, n. 5, p. 220-222. 
DOI: 10.14807/ijmp.v7i1.388

CHAVES, J. (2010) Melhores Práticas para Garantia de Sustentabilidade de Melhorias Obtidas Através de Eventos Kaizen. Dissertação (Mestrado em Engenharia de Produção) Universidade de São Paulo, São Carlos.

CHEN, J. C.; DUGGER, J.; HAMMER, B. (2000). A Kaizen Based Approach for Cellular Manufacturing Design: A Case Study. The Journal of Technology Studies, v. 27, n. 2 , p. $19-27$.

CORRÊA, O. J.; VIEIRA, G. E. (2008). Kaizen 3p - Preparação do Processo de Produção: Estudo de Caso de Melhoria Contínua em Indústria Cosmética. Anais do XV Simpósio de Engenharia de Produção, Bauru-SP.

GIL, A. C. (2010). Como elaborar projetos de pesquisa. 5. ed. São Paulo: Atlas. GONZALEZ, R. V. D.; MARTINS, M. F. (2011). Melhoria contínua e aprendizagem organizacional: múltiplos casos em empresas do setor automobilístico. Gestão e Produção, v. 18, n. 3, p. 473-486.

HARRINGTON, J. (1997). Gerenciamento total da melhoria contínua. São Paulo: Makron Books.

IMAI, M. (1996). Gemba - Kaizen: estratégias e técnicas do Kaizen no piso de fábrica. São Paulo.

KOSANDAL, P.; FARRIS, J. (2004) The strategic role of the kaizen event in driving and sustaining organizational change. VirginiTech.

KARLSSON, C.; AHLSTRÖM, P. (1996). Assessing changes towards Lean production. International Journal of Operation and Production Management. V. 16, n. 2, p. 21-41.

LIMA, C. (2010). Evento Kaizen na Indústria Automobilística Brasileira: Estudo de caso. Dissertação (Trabalho de Conclusão de Curso) - Universidade de São Paulo, São Carlos.

MALIK S. A.; YE ZHUANG, T. (2006). Execution of Continuous Improvement Practices in Spanish and Pakistani Industry: A Comparative Analysis. IEEE International Conference on Management of Innovation and Technology, v. 2, p. 761-765, Singapore.

MICHALSKA, J.; SZEWIECZEK, D. (2007). The 5S methodology as a tool for improving. Journal of Achievements in Materials and Manufacturing Engineering, v. 24, n. 2, p. 211-214.

PASCAL, D. (2008). Produção Lean Simplificada. Porto Alegre: Artmed.

PEINADO, J.; GRAEML, A. R. (2014). A Prática da Gestão de Operações nas Organizações. RAE , Revista de Administração de Empresas, FGV-EAESP, São Paulo, v. 54, n. 5, p. 483-495.

ROTHER, M.; SHOOK, J. (2003). Aprendendo a Enxergar. São Paulo: Lean Institute Brasil.

SINGH, J.; SINGH, H. (2009). Kaizen Philosophy: A Review of Literature. The Icfai University Journal of Operations Management, v. VIII, n. 2.

WOMACK, J. P.; JONES, D. T.; ROOS, D. (1992). A máquina que mudou o mundo. Campus. 5ed. Rio d e Janeiro. 
INDEPENDENT JOURNAL OF MANAGEMENT \& PRODUCTION (IJM\&P)

http://www.ijmp.jor.br

v. 7, n. 1, January - March 2016

ISSN: 2236-269X

DOI: 10.14807/ijmp.v7i1.388

WOMACK, J. P.; JONES, D. T. (1998). A mentalidade enxuta nas empresas:

elimine o desperdício e crie riqueza. 4ed. Rio de Janeiro. 